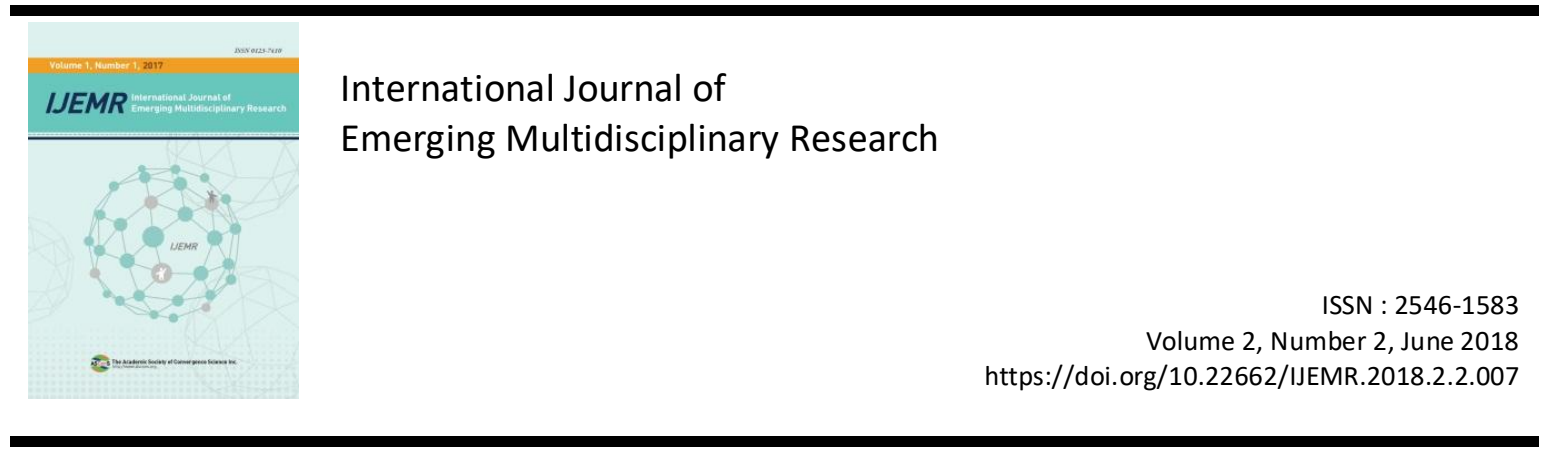

\title{
Journey of GST before Implementation
}

\author{
Mr. Arun Gautam ${ }^{1}$ and Dr. Tina Shivnani² \\ ${ }^{1}$ Research Scholar, Dept. of Commerce Manipal University, Jaipur, 303007, Rajasthan, India \\ ${ }^{2}$ Assistant Professor. Dept. of Commerce, Manipal University Jaipur, 303007, Rajasthan, India
}

\begin{abstract}
Background/Objectives: GST is one of the most important tax reforms in India which was started by Vishwanath Pratap Singh in 1986, but due to various problem it is still pending. Methods/Statistical analysis: Then again GST was proposed in 1999 by prime minister Atal Bhiari Vajpayee, but still pending due to political issue, in 2002, again Vajpayee government recommended GST. This recommended process continuous goes from long time, but in 2014, the NDA government was introduced the GST bill in Rajya Sabha and Lok Sabha. Finally, in Aug 2016. The GST was launched at mid night 1 July 2017, by the president of India, Pranab Mukherjee. Several big challenges is there before implement the GST such as type of GST distribution (CGST, SGST, IGST and UGST), a lot of discussion has taken place in the parliament about the distribution and rate of GST. Findings: After survey of tax rate Mr. Jaitely was finalized tax rate $0 \%, 5 \%, 12 \%, 18 \%$ and $28 \%$. The Centre will compensate the states for any loss due to GST for the first five years. Improvements/Applications: Before the implementation of GST a five member panel of minister, discuss the problem of online procedure of problem.
\end{abstract}

\section{Index Terms}

India, Indirect Tax, GST, GOODS and Service Tax, Tax.

\section{Corresponding author: Arun Gautam}

aryan20gautam@gmail.com

- Manuscript received April 16, 2018.

- Revised June 11, 2018 ; Accepted June 13, 2018.

- Date of publication June 30, 2018.

(C) The Academic Society of Convergence Science Inc.

2546-1583 @ 2017 IJEMR. Personal use is permitted, but republication/redistribution requires IJEMR permission. 


\section{INTRODUCTION}

Tax collection is the way toward gathering Taxes from natives in view of their profit and property. The cash raised from tax assessment underpins the administration and enables it to support polices and court have a military, fabricate and keeps up the street alongside numerous different administrations.

Tax collection are of two sort Direct Tax and Indirect Tax .Direct Tax are those assessment which are paid straightforwardly pay by the citizen while Indirect Tax are those which are paid by implication to the administration by the payer.

Backhanded Tax are focal deal assess, esteem included expense, extract obligation, traditions obligation, Service impose, stimulation charge, extravagances assess and so on. Entire Indirect Tax is change in GST barring traditions obligation.

In India, GST is a roundabout assessment which was demanded by the governments. It was presented by Finance Minister of India - "Arun Jaitley" as the Constitution, 122nd Amendment Bill Act 2016.

GST is a change of roundabout Taxation in India. Amalgamating a few Central and State charges change over in single assessment. The effortlessness of the duty should prompt simpler organization and authorization. From the shopper perspective, the greatest favorable position would be in the term of diminishment in the general taxation rate on merchandise, which is as of now assessed at $25 \%-30 \%$, free development of products starting with one state then onto the next without ceasing at state fringes for a considerable length of time for paying of state expense or passage duty and lessening in paper work to expansive broaden [1].

GST Tax Rate is $0 \%, 5 \%, 12 \%, 18 \%$ and $28 \%$ apply on goods in India and GST Bill Passing in Rajya Sabha in Aug, 2016.

\section{LITERATURE REVIEW}

Mondal and Dipak (2016) talk about in their paper "Long street ahead for GST before usage" that GST might be a representativeness by one year from now with the Rajya Sabha passing the GST Constitution Amendment Bill on August 2016. The Constitution Amendment Bill is enormous difficulties for the Central government - complete and passage of the GST Bill (the Amendment Bill just changes the Constitution to empower the Center and states to charge GST), approval of the Amendment Bill by $66 \%$ larger part impressively the state social affairs, Model GST law released two or three months back and rollout of the IT structure that will strategy billions of records and bits of information that associations will exchange every month under the new system.

The certified test will manufacture an agreeableness on the model GST law and draft rules for Central GST, Integrated GST and State GST, affiliation district GST. The precepts for the underlying two will be indicated in the GST Bill. The Political social occasions require an open consideration and voting in the two spots of Parliament, and need the GST Bill to be tabled as a reserve Bill and not a money Bill. A cash Bill can't be slowed down in the Rajya Sabha. GST has least exceptions, sensible low rate likewise give input charge credit framework.

The Center will remunerate the states for any misfortune because of GST for the initial five years. Assembling states, for example, Tamil Nadu, Maharashtra and Gujarat have opposed GST in the past because of fears over income misfortune as it includes a move from beginning based tax collection to utilization based tax assessment. This implies the state where products and enterprises are expended has the privilege to impose them. Successfully, various states have started giving mishap figures. Tamil Nadu is ensuring that it will lose Rs.9270 crore, while Maharashtra and Gujarat are declaring mishaps of Rs.14,000 crore and Rs.11,000 crore, exclusively, reliably. The Center should think of its own gauge before choose the remuneration. This could prompt Center-state question and strain the previous' funds [2].

Bhatia, Himanshu (2010) examine in their paper "India Releases GST Discussion" India forced separate backhanded expenses on products and ventures at different levels. The expenses that were paid on products and enterprises at the government level were not respectable against each other and furthermore different circuitous charges, for example, extravagance and diversion were not coordinated with VAT/Service Tax. Thus with the vision of reforming the current indirect taxing system, during the Union Budget 20072008 our then Finance Minister proposed the idea of combining all the indirect taxes into one. This came to be known as Goods and Services Tax (GST).

GST model consisted of two levels i.e. Federal GST (Central GST (CGST)) and State GST (SGST) which were to be implemented through multiple statuses. Basically GST serves the purpose of integrating all the indirect taxes into one. For interstate transaction IGST (Integrated GST) model was adopted by appropriately aligning and integrating GST and CGST. Export of goods and services from India were zero rated. GST consisted of three rate levels; one for the goods that were considered as necessary items or the daily needs, one standard rate for other goods and a special rate for 
precious metals. Supplies for the domestic tariff to the Special Economic Zone (SEZ) would also be zero rated. GST and CGST were to be imposed on the import goods and import services.

GST was not applicable to real property, petroleum and alcohol industries according to the discussion paper. Some state level taxes such as octroi, purchases tax on food, grains, electrical duty were not included in the GST legislation. Cross credit between CGST and GST was not permissible except during interstate transaction, here is where IGST came into play. Thus this review discusses about the first discussion paper discussed by the Finance Minister.

\section{OBJECTIVE OF STUDY}

- To describe the problem of applying GST in India.

- To outfit data for additionally inquire about work on GST.

\section{RESEARCH METHODOLOGY}

Being a logical research it depends on auxiliary information of diaries, articles, daily papers and magazines. Considering the destinations of concentrate illustrative write look into configuration is received to have more precision and thorough examination of research ponder. The open auxiliary information is seriously utilized for inquire about investigation.

\section{ANALYSIS}

The researcher has identified the following problem for the implementation of GST in India. These are as follows:-

\section{A. Passing bill in Rajya Sabha}

GST was begun by Vishwanath Pratap Singh, Finance Minister in Rajiv Gandhi's administration, since 1986, with the presentation of the MODVAT yet because of political issues and different other issue it was pending after some time, Value Added Tax at the state level was talks by Manmohan Singh and the Finance Minister P V Narasimha Rao. "Merchandise and Ventures Tax (GST)" was proposed by Prime Minister Atal Bihari Vajpayee and his monetary warning board (previous RBI governors IG Patel, Bimal Jalan and C Rangarajan) in 1999.

Atal Bihari Vajpayee make a board of trustees headed by Asim Dasgupta (fund Minister of West Bengal), to plan a GST demonstrate. Advisory group was additionally did took a shot at the back-end innovation and coordination's for revealing a uniform tax assessment administration in the Country. Later came to be known as the GSTN, in 2017[3].

In 2002, the Vajpayee government for per pass of tax reforms formed force under Vijay Kelkar NDA government not usage GST because of political issues and different other issue, however in 2005, twelfth Finance Commission, the Kelkar board of trustees suggested taking off GST. The new Congress-drove UPA government Finance Minister P Chidambaram in February 2006 same worked proceed do, proposed a GST actualize in 1 April 2010. Anyway in 2010, Asim Dasgupta surrendered as the leader of the GST advisory group because of West Bengal political issue. Dasgupta was primary move on GST [3]

In 2014, the NDA government was picked into control under the activity of Narendra Modi. Seven months after the advancement of the Modi government, the new Finance Minister Arun Jaitley displayed the GST Bill in the Lok Sabha, where the BJP had a larger part.

In February 2015, Jaitley given another due date of 1 April 2017 to execute GST. In May 2016, the Lok Sabha passed the 122nd Constitution Amendment Bill. Nonetheless, a few contradictions on GST charge by the restriction, again charge send in Rajya Sabha board of trustees. At long last in August 2016, the Amendment Bill was passed. next 15 to 20 days, the President Pranab Mukherjee confirmed GST charge 18 state gave his consent to it and shaped 22 individuals board of trustees for look GST laws .GST charge passed entire India with the exception of Jammu and Kashmir from 1 July 2017, The Jammu and Kashmir state governing body passed its GST follow up on 7 July 2017.

\section{B. Launch-}

The GST was imposed at midnight on 1 July 2017 by the President, Pranab Mukherjee, and PM, Narendra Modi. In the Central Hall of the Parliament, GST Bill was propelled at midnight (30 June -1 July), it is history of Indian Constitution.

It is one of only a handful couple of midnight sessions that have been held by the parliament - the others being the disclosure of India's independence on 15 August 1947, and the silver and splendid festivals of that occasion [4].

The Constitution Amendment Bill is only the initial step and a few major difficulties anticipate the Central government - complete and area of the GST Bill (the 
Amendment Bill just changes the Constitution to empower the Center and states to force GST; the honest to goodness utilization will require the passage of the GST Bill), endorse of the Amendment Bill by $66 \%$ larger part altogether the state social affairs, settling of flaws in the Model GST law released two or three months earlier and rollout of the IT establishment that will method billions of reports and bits of information that associations will exchange every month under the new system.

The due date of April 1, 2017 the lawmaking body has set itself for the last rollout is longing, without a doubt. Law Making

The lawmaking body should encounter the pound of Parliamentary techniques again to get the Constitution Amendment Bill go in the Lok Sabha. This will require $66 \%$ prevailing part anyway won't be troublesome given that the choice National Democratic Alliance has 336 seats as against the 362 votes that it will require. Getting it supported by 50 for every penny (no under 15) social events won't be troublesome either as 14 out of 29 states are controlled by the Bharatiya Janata Party, or BJP, or its partners. "This should be possible without trouble as 12 states are managed by the BJP and around two-third of India's 29 states are utilization concentrated thus will pick up from GST," says a HSBC Global Research report.

\section{GST distribution:}

Lok Sabha has passed the CGST, IGST, UTGST and the SGST Bill 2017 (Compensation Bill) tabled in the Parliament. The GST bills presented as cash bills, will guarantee a smooth section through the Rajya Sabha. The state congregations should pass the State GST charges (SGST). The GST chamber will soon choose point by point GST principles and rates of individual products.

The GST has supplanted in excess of twelve focal and state expenses or VAT with a mean to make a consistent brought together market for the $\$ 2$ trillion Indian economy. The GST just like demonetization, is a step to help reduce the costs for the common man. There are a lot of grey areas to be covered and rules taxes modified as we move along. The important thing is the first step which the government has taken.

The earlier government has thought of this implementation too, but they didn't implement it like the current government. The tax now collected will be equally divided among the Centre and the states. This implementation is not ruled in Jammu and Kashmir[5].

\section{Tax rate Determination:}

Now that the government has brought GST into the picture, it is seen that it will replace multiple taxes at the central and state level, which will therefore result in the peak growth of India's market value. Before its implementation, a lot of discussion had taken place in the Parliament. According to Mr. Jaitely, it was a significant step that has been taken by the government. He also said that the approval of GST is a milestone in the economic history of the country[5].

The four parts of legislation provide a peak tax rate of about $40 \%$. The government has already set up the working groups to take up the issued face by various sectors of people involved into business or industries, after survey of tax rate Mr. jaitely , finally was decided tax rate $0 \%, 5 \%, 12 \%, 18 \%$ and $28 \%$.

\section{E. Compensate the states for revenue loss:}

The Center will repay the states for any misfortune because of GST for the initial five years. Assembling states, for example, Maharashtra, Gujarat \& Tamil Nadu have opposed GST in the past because of fears over income misfortune as it includes a move from inception based tax collection to utilization based tax assessment. This implies the state where products and ventures are expended has the privilege to assess them. Officially, numerous states have begun giving misfortune figures. Maharashtra and Gujarat are asserting misfortunes of Rs.14,000 crore and Rs. 11,000 crore, while Tamil Nadu is guaranteeing that it will lose Rs.9270 crore, individually, consistently. The Center should think of its own gauge before choose the pay. This could prompt Center-state debate and strain the previous' accounts.

According to Section 7 of the Goods and Services Tax (Compensation to States) Act, 2017, states and Union regions with lawmaking bodies must be made up for income misfortunes emerging out of execution of GST amid the five-year progress period starting from the date on which the SGST Act of the concerned state has come into drive.

The GST (Compensation to the States for Loss of Revenue) Act has anticipated the income development for states amid the five-year change period to be 14 for each penny and the money related year of 2015-16 has been settled as the base year for estimation of remuneration sum, with the base year assess income including states' expense incomes from state VAT, Central deals charge, section impose, octroi, neighborhood body impose, assesses on extravagances, charges on promotions.

Nonetheless, any income among these assessments identified with supply of liquor for human utilization, 
diversion impose exacted by the states yet gathered by neighborhood bodies and oil based goods not some portion of GST will be avoided from the base year income[6].

The Act additionally expresses that the pay payable to a state should be temporarily ascertained and discharged toward the finish of at regular intervals and might be at last computed for each budgetary year after the receipt of definite income figures, as examined by the CAG of India.

On the off chance that, any abundance sum has been discharged as pay to a state in any money related year amid the change time frame, according to the reviewed figures of income gathered, the overabundance sum so discharged might be balanced against the pay sum payable to such state in the consequent budgetary year.

Centre government pays revenue losses is Rs.8698 crore to states and UTs. Payout stands at $58 \%$ of total Rs. 15060 cr raised from cess in first 2 months of GST.

"A lot of to and fro is happening between the states and the Centre regarding the compensation payout. Rs. 8698 crore is a provisional figure and may change at the end of the year when revenue numbers would be finalized. Compensation payout is also expected to increase going ahead as July numbers were significantly lower due to high VAT collections by states," one of the officials said $[7,8]$.

\section{F. Online procedure:}

Before execution of GST a five-part board of pastors, under the chairmanship of Bihar Deputy CM Sushil Kumar Modi of the BJP, met to talk about the issues organizations are looking in documenting their GST returns. With the point of making a typical assessment i.e. GST. It additionally includes a total upgrade of the expense documenting framework, compelling dealers to utilize another recording programming that has neglected to convey. Modi supposedly said that the undertaking of settling the new Goods and Services Tax entryway [9].

Businesses must file their GST returns using the websites and mobile apps run by the GST Network, the non-profit, non-governmental entity responsible for the rollout of the tax. The panel of Ministers plans to meet every 15 days to examine the functioning of the network, and Modi has said he expects $80 \%$ of the problems in the system.

Following problem that faces during the online procedure of GST fill

\section{Failure in to $\log$}

"There are many technological issues in the network such as the logging-in problem," he said. "Some traders who have transitioned to GST and have received their temporary numbers to $\log$ in are unable to do so because the network is busy."

\section{Returns declined}

Another problem reported by traders is of the online system declining their returns despite fulfilling the specifications laid down in the Goods and Services Tax rules. People to complain that they could not file their 3B returns as the portal returned an error saying "invalid return type".

\section{Design bugs}

Problems were evident during the introduction of the GST and the firm expected these to be fixed with the appointment of the ministerial panel. "There are many such implementation issues which are there in the system but you will have to wait till the new upgraded system kicks in to see which ones remain,"

\section{Deadlines pushed back}

As the government scrambles to fix these glitches, the Goods and Services Tax system has also failed to support the last-minute rush in filing of returns, as a result of which deadlines are being extended continuously [10].

\section{CONClusion}

GST is very important aspect of India economy. Day by day is increasing the consumption and production of goods and service furthermore, due to assortment of expenses in current assessment administration organization complexities and consistence cost is additionally quickening. In this way, A streamline, client - amicable and just expense framework is required which can be satisfied by execution of GST. Its execution remains for an intelligent duty framework.

There are different difficulties of amid usage as talked about in above paper like Bill go in Rajya Sabha, GST compose, Rate of GST write , Rate of GST appropriation in state and central government, Revenue misfortunes remuneration of State, Online system of and so forth. They require more logical research to determine the expense structure framework as indicated by the different partner issue, examinations the different issue amid the procedures of the GST. 


\section{REFERENCES}

[1] Bhatia, Himanshu (2010) .India Releases GST Discussion. International Journal of Research Granthaalayah, 3(12), 133-141.

[2] Debnath, P. (2016). Implementation of Goods and Service Tax (GST) in India and its Control over the Tax Collection. Journal of Commerce and Trade, 11(1), 28-35.

[3] Greene, N. L. (2011). Rule of Law in Morocco: A Journey towards a Better Judiciary through the Implementation of the 2011 Constitutional Reforms. ILSA J. Int'l \& Comp. L., 18, 455.

[4] Mondal \& Dipak (2016). Long road ahead for GST before Implementation. Ministry of Finance, Government of India JMAJ 58, no. 4 (2015): 245.

[5] NAIDU, R. (2015). Malaysian Medical Association. Japan Medical Association journal: JMAJ, 58(4), 245.

[6] Singh, R. P (2017). An Analytical Study of Goods and Services Tax (GST) Bill in India. International Journal of Trade and Commerce-Iiartc.Rev., 33, 705

[7] Shivnani, T., \& Jampala, M. C. B. (2017). A Journey of Goods \& Services Tax (Gst) In India: An Overview. Journal of Commerce \& Accounting Research, 6,3.

[8] Fintec (2017) Markets make a strong start supported by GST. Systems Research and Behavioral Science, 9(4), 1-8.

[9] Singh, R. P (2017). An Analytical Study of Goods and Services Tax (GST) Bill in India. International Journal of Trade and Commerce-Iiartc.Rev., 33, 705.

[10] NAIDU, R. (2015). MALAYSIAN MEDICAL ASSOCIATION. Japan Medical Association journal JMAJ, 58(4), 245. 